https://doi.org/10.18485/iipe_euchanges.2021.ch9

\title{
THE EUROPEAN UNION BETWEEN ITS REGIONAL ROLE AND ITS GLOBAL AMBITIONS IN INTERNATIONAL RELATIONS
}

\author{
Duško LOPANDIĆ ${ }^{1}$ \\ Jelica GORDANIĆ
}

\begin{abstract}
The paper examines regional actions of the European Union, the major lines of its evolution, as well as the transformation of the strategic role of the EU and its continental position as a regional power. Despite being considered a successful regional actor, the EU is facing multiple geostrategic regional challenges, as well as fragmentation processes, which are especially characterized by Brexit. The paper also examines the role of the EU as a global actor. The Common Foreign and Security Policy (CFSP) is faced with the lack of genuine European identity, diversity of interests, and inefficiency of institutions. Besides the progress of the Common Security and Defence Policy (CSDP) from soft to hard power, NATO remains the backbone of European security. The role of the EU in the UN had been weakened after Brexit. The authors consider the EU Global Strategy from 2016 as a possible Renaissance of the EU Common Foreign and Security Policy and a factor of empowerment of the EU regional role and global ambitions in international relations.
\end{abstract}

Keywords: EU, regional actor, global actor, Brexit, NATO, EU Global Strategy.

${ }^{1} \mathrm{PhD}$, Ambassador, Ministry of Foreign Affairs of the Republic of Serbia. E-mail: dulopand@yahoo.com.

Opinions expressed in this article are the author's own and do not reflect the view of Ministry of Foreign Affairs of the Republic of Serbia.

${ }^{2}$ Research Fellow, Institute of International Politics and Economics, Belgrade, Serbia. E-mail: jelica@diplomacy.bg.ac.rs

The paper presents findings of a study developed as a part of the research project "Serbia and challenges in international relations in 2021", financed by the Ministry of Education, Science, and Technological Development of the Republic of Serbia, and conducted by Institute of International Politics and Economics, Belgrade. 


\section{INTRODUCTION}

In this paper, we will present the role and importance of the European Union (EU) as a regional factor on the European continent, and on the other, its ambitions to act and influence on global issues. Changes in the international order during the 21st century have significantly affected the international ambitions of the EU, as well as its position on the threshold of the third decade of this century (R. Has, 2017; T. Judt, 2005).

In the first part of this paper, we will deal with the evolving role and importance of the EU in Europe over the last three decades, from the signing of the Maastricht Treaty (1992) and the transformation of the three economic communities into a political, economic and monetary union project, encompassing the entire continent. The ultimate goals of the creation and development of the European communities (i.e., the European Union) have never been quite clearly defined, so they have evolved over time, according to the circumstances and encounters of various challenges and crises. By the end of the 20th century, Europe was dominated by centripetal trends ${ }^{3}$. On the contrary, this century has been characterized by fragmentation processes, which are especially illustrated by Brexit.

The second part will be dedicated to the analysis of the global ambitions of the EU envisaged in its Global Strategy from 2016. We will point out the realization of common strategic goals, obstacles standing in its way, as well as the EU's relations with NATO and its role and action in the United Nations.

\section{THE EUROPEAN UNION AS A REGIONAL FACTOR IN EUROPE}

\section{The role of the European Union in building a "new European architecture"}

The beginning of the 1990s represented a time of the transformation of the bipolar world into a unipolar system dominated by the United States, along with its allies. After the disappearance of the Eastern bloc, "the Atlantic Alliance was stronger than ever before" (Z. Bzezinski, 2009, p. 20). In this context, the question of building a "new European architecture" arose, which would be developed strategically around NATO, and politically and economically

\footnotetext{
${ }^{3}$ With the exception of former socialist federations (USSR, Yugoslavia, and Czechoslovakia) that were dissolved after the collapse of the USSR (1991).
} 
around the European Union - as the backbone of the further gradual transformation of the continent into a kind of confederation or "postmodern empire" (U, Beck, E. Grande, 2006, p. 71). In this process, the key stages were the unification of Germany (1990) and then the transformation of the former integration composed of three European communities into a political, economic, and monetary union (European Union - EU 1993). It was followed by the gradual inclusion of other European countries in the EU and then the strategically important integration of the countries of Central and Eastern Europe (up to the borders of the former USSR). This process, which went largely in parallel with NATO enlargement, culminated in the "big bang", i.e., the enlargement of the European Union from 15 member states to 25 (2004), or 27 member states in 2007, i.e., practically by doubling the membership in a relatively short period of about a decade.

During the period of preparations and negotiations for EU enlargement of the States of Central and Eastern Europe (CEE), the Union played a key role as a force that projects its "transformational power" on the candidate countries (H. Grabbe, 2006). CEE countries have drastically changed their socio-economic system under its influence, together with very rapid economic development encouraged by significant foreign direct investment, as well as budget incentives from EU funds ${ }^{4}$.

In addition, the key geostrategic influence and the role of the United States should not be forgotten. After unsuccessful interventions by the EU countries at the beginning of the conflict in the former Yugoslavia, the United States has on several occasions played a key role in military-political interventions in Southeast Europe. That led to the end of the war in $\mathrm{BiH}$ (Dayton Accords 1995) and the bombing of Serbia, resulting in the international control over the Serbian province of Kosovo and Metohija (1999).

In other words, the relative geopolitical, economic and social stability achieved in Europe after the fall of the Berlin Wall and later on ${ }^{5}$, was a

4 The average GDP of Romania compared to the average in the EU increased in the period 1999-2018 from 26\% to 65\%, while the average of Bulgaria increased from $27 \%$ to $51 \%$ of the Union average (calculated per unit of purchasing power - PPP). A dynamic convergence trend was noted by all other CEECs (ESI Report, 2020, p. 17).

${ }^{5}$ Here we exclude the situation in the former Yugoslavia, i.e., the conflicts in some ex-Yugoslav republics, as well as destabilization processes and conflicts on the outskirts of the former USSR (Moldova, Caucasus, etc.), or Europe's neighboring areas (Middle East, North Africa). 
consequence, on the one hand, of the EU and its enlargement policy, but also of a relatively coordinated transatlantic cooperation between the US and the EU during the presidencies of G. W. H. Bush Senior (1989-1993) and B. Clinton (1993-2001). However, with the policy of the administration of the President of the US, G.W. Bush Jr. (2001-2009 - especially after the US conflict with some European allies over the US intervention in Iraq - 2003), there was a gradual distancing between the US and the EU on a number of important geostrategic issues, which continued during the presidency of $\mathrm{B}$. Obama (2009-2017) and especially intensified during the D. Trump administration (2017-2021).

This trend of the relative weakening of the transatlantic alliance coincided, perhaps not accidentally, with a series of crises in the European Union (Fabbrini, 2015), which ultimately led to a change in the role of the $\mathrm{EU}$ and its reduced influence on various important geopolitical issues in Europe and its surroundings. In this context, the following events stand out:

- the failure of the referendum on the "Constitution of Europe" in France and the Netherlands (2003), which, together with a big bang, caused a "crisis of identity" in the EU;

- the long-term phenomenon of "enlargement fatigue" in the EU countries after the big bang (2003-2007), which significantly affected the further implementation of enlargement policy (especially towards the Western Balkans) ${ }^{6}$;

- the severe economic and financial crisis of public debts (2008-2012), which threatened the very existence of the euro area and opened the question of the functioning of the monetary union;

- the great migrant crisis (2015-2016), which was the result of the civil war in Syria, but at the same time a far-reaching consequence of the deep destabilization of the Middle East;

- decision of British voters in the 2016 referendum for Great Britain to leave the membership in the EU.

Although the EU has managed to overcome a number of crises, they have in some measure affected its international credibility and influence. Germany and France, whose cooperation represents the geostrategic "backbone" of the functioning and survival of integration, have maintained an appropriate level of cooperation that enables the survival and possible development of the Union.

${ }^{6}$ The exception was Croatia's accession to the EU in 2013. 
The crisis caused by the 2020 COVID-19 pandemic also encouraged some positive reactions, such as the decision to establish an Economic Recovery Plan ("Future Generations" Fund). On this occasion, for the first time, Germany accepted the request of its partners that the EU (i.e., the European Commission) issues solidarity bonds and borrow on behalf of all members of the Union (Roloff, 2020). On the other hand, the phenomena of political, economic "differentiation"7 and regional fragmentation, i.e., deeper divisions between the member states of the Union, are still present, either in terms of relations with the euro area (north/south divisions), or west/east divide (migrant issues) or in the form of tactical regrouping into smaller subregional groups (such as the Visegrad Group or the Baltic countries) as a way of strengthening the position of smaller states in the EU decisionmaking process (Dyson, Sepos, 2010).

\section{The main geostrategic regional challenges for the EU on the threshold of the third decade of the XXI century}

The position and influence of the EU in recent years, and especially after Brexit, stem from the fact that the Union is no longer seen as a system aimed at encompassing the whole of the European continent one day. It now represents only one of the (key) actors of interstate cooperation in continental Europe. "Multipolar Europe" is a reality today (Krastev, Leonard, 2010). Regardless of crises, the EU remains a key element and factor of the European geopolitical architecture whose internal market and various internal and foreign policies have great significance, both for European countries and the whole world (Telo, 2016). Therefore, the position of its neighbours, as well as of more distant countries, depends on the future development of the EU. We should also keep in mind that the geopolitical position and stability of the EU and Europe as a whole, are significantly influenced by the state of transatlantic relations.

At the beginning of the third decade of the 21st century, it can be stated that the EU has not overcome the centrifugal trends caused by multilateral

\footnotetext{
7 "Differentiated integration is the process whereby European states, or sub-state units, opt to move at different speeds and/or towards different objectives with regard to common policies. It involves adopting different formal and informal arrangements (hard and soft), inside or outside the EU treaty framework (membership and accession differentiation, alongside various differentiated forms of economic, trade and security relations)." (Dyson, Sepos, 2010, p. 4).
} 
internal and external crises. French President Macron's proposals for strengthening "a sovereign, united" European Union are opposed to populism, as well as the tendency to strengthen the role of nation-states in the decision-making process (Mirel, 2020). The EU is more and more organized through concentric circles - its centre and periphery, plus a third circle composed of the candidate and aspirant countries. Around the European core, there is the circle of neighbouring "powers" (UK, Russia and Turkey).

The position of the European Union and its credibility and action in the European environment is particularly affected by the following issues from its environment:

- future articulation of the EU's relations with the United Kingdom, as a significant partner in Euro-Atlantic relations. The UK will continue to be an important geopolitical factor as a nuclear power, an economically and politically important country. Although the UK and EU managed to reach a "soft Brexit" agreement at the last minute, the UK will be both a partner and a discreet competitor to the Union in practice (Sampson, 2019).

- redefining the EU relations with Turkey. Turkey is a "perpetual" candidate for membership of the Union, with which accession negotiations have been halted. This country plays a very active regional role. During the formal negotiations on accession to the EU (which started in 2005), Turkey went through two phases: in the first phase, the country was rapidly reformed and "Europeanized". However, with the strengthening of the authoritarian and pro-Islamic regime of President Erdogan, the process of Turkey's accession was stopped. This country was never fully accepted as a possible EU member by a number of its Member States. In addition, we can add serious geopolitical problems, such as the Cyprus issue, Turkey's actions in the Eastern Mediterranean and its relations with Greece.

- the issue of Ukraine and the EU relations with Russia. The EU relations with Russia seriously deteriorated after political changes in Ukraine in 2014. Russia's annexation of Crimea, the conflict in eastern Ukraine (Donbas), EU sanctions against Russia, as well as the great energy dependence of a number of EU countries on Russia, are just some elements of the Union's complex relations with the geographically largest country in the world (van der Togt, 2020). The Ukrainian conflict also fits into the broader picture of Russia's deteriorated relations with the transatlantic allies. 
- EU action towards the Middle East. A long term EU "Mediterranean policy" showed the limits of its foreign influence. "The Arab Spring", instead of democratization, resulted in a number of conflicts. The Syrian and Libyan crises and wars had direct consequences for the stability of Europe in the form of Islamic terrorism, as well as a large and almost continuous wave of refugees. Despite the huge interests of some EU countries in the region, they were not able to bring the appropriate stability in this volatile area, where a number of outside actors are present (including the US, Russia, Turkey, Iran, etc.).

- a further evolution of the enlargement policy. The loss of dynamism in the EU WB enlargement policy has reduced its capacity (which still exists) to effectively influence the evolution of the internal situation and the position of the WB countries. By using different instruments and through various forms of diplomatic actions (including, for example, mediation in the Belgrade-Priština dialogue, actions in Northern Macedonia, $\mathrm{BiH}$, etc.), the Union has managed to exercise some positive impact on stability in SEE (Ćemalović, 2020). On the other hand, oscillations in enlargement policy have led to a situation reminiscent of endless EU negotiations with Turkey. The "new methodology" for enlargement negotiations, adopted by the EU, at the initiative of France, in 2020, envisages essentially only a kind of partial - sectoral integration of the WB candidate countries into the EU, which will form a kind of "second periphery" with regard to the political and economic core. The ultimate goal - full membership - remains vague and out of the focus of practical policy.

\section{GLOBAL AMBITIONS OF THE EU}

\section{EU Global Strategy and obstacles for the global role of the EU}

"We live in times of existential crisis, within and beyond the European Union. Our Union is under threat (...) To the east, the European security order has been violated, while terrorism and violence plague North Africa and the Middle East, as well as Europe itself. Economic growth is yet to outpace demography in parts of Africa, security tensions in Asia are mounting, while climate change causes further disruption. In achieving these goals, the EU must stand united. The combined weight of a true union has a potential to deliver prosperity, security and make a positive difference in the world." These words of Federica Mogherini in the Global Strategy for 
the European Union's Foreign and Security Policy describe the need for the EU's global reinforcement.

The EU's ambitions in global politics and international relations have caused much public and academic attention. A Global Strategy for the European Union's Foreign and Security Policy (EU Global Strategy) from 2016 highlights global priorities of the EU:

- security of the Union,

- state and social resilience to East and South,

- an integrated approach to conflicts and crisis,

- cooperative regional order and

- global governance for the $21^{\text {st }}$ century.

Written on paper, it looks perfectly reasonable and concise. Today's multipolar world is a good opportunity for the EU's better positioning as a global actor. This circumstance raises a question: "Can EU's global ambitions cause rivalry with other actors?" The answer is certainly positive. The US, China, and new emerging forces like Brazil and India have similar global goals like the EU. These actors are in a better position than the EU when it comes to achieving a global role. They are states. The EU is a unique type of actor, a mixture of state and international organisation. It is a supranational organization in which states share sovereignty. Unity is a key factor for the global role of the EU. It is much harder for the EU to create and maintain unity having in mind disagreements on controversial political issues like Kosovo, relations between the EU and Turkey, the migrant crisis, etc.

The institutional structure of the EU and complex decision-making process can be considered as an obstacle in the global role of the EU. The European Council has a leading role in the formulation of the CFSP. The High Representative and the European External Action Service must chair the CFSP. In this case, there is a need for coordination as the High Representative is the Vice President of the Commission. In relation to the CFSP, the High Representative can consult the European Parliament and consider its views in the formulation of the CFSP. The European Parliament has oversight over the CFSP, as it approves its budget. This complexity is slowing down the speed of the CFSP (Lopandić, 2018, p. 260; Khosla, 2019, p. 13).

Three years of implementation of the EUGS have shown significant progress on many levels: European security and defence, the goal of strategic autonomy as set out by the Council; the reaffirmation of the perspective for the Western Balkans; preserving the nuclear deal with Iran; the step change in the partnership with Africa and strong support of the UN 
reforms. In achieving these goals, the EU has intensified its cooperation with international and regional organizations and non-state actors. The EU has deepened its partnerships with all countries of the Middle East and North Africa, and regional organizations such as the League of Arab States, the countries of the Gulf Cooperation Council, and the Organization of Islamic Cooperation. The EU has demonstrated commitment to the deepening of multilateralism by reaching the political and trade agreements such as with Canada and Japan, as well as pursuing negotiations with Mercosur, Mexico, Chile, Australia, and New Zealand (The European Union's Global Strategy Three Years On, Looking Forward, Brussels, 2019. p. 10).

The EU was facing a hard period - Brexit, the migrant crisis, terroristic attacks, etc. The migrant crisis had caused "fears of the possible Islamization of Europe" (Gordanić, 2019, p. 16). This had a serious consequence - the rise of populist parties and the crisis of the European identity. Issues like the refugee crisis have been used by populist parties to provide a radical rethink of the EU's foreign and security agendas. Populist parties "reject European integration because they believe it weakens national sovereignty, diffuses self-rule and introduces foreign ideas. They oppose European integration for the same reasons that they oppose immigration: it undermines national community" (Barbé \& Morillas, 2019, p. 758). These tendencies are serious threats to democracy, human rights, the rule of law within and outside the $\mathrm{EU}$, as well as the threat to the EU's global ambitions.

A report on three years on implementation of the EU Global strategy states that the EU "must continue to invest consistently in our collective capacity to act autonomously and in cooperation with our partners." The politicization of strategic issues and lack of unity among members are key obstacles for the EU in acting autonomously and achieving the status of the global actor, competitive to the US, China and Russia. Besides, the Report on three years of implementation of the EU Global Strategy states: "Europeans do not aim (...) playing into global power competition and rivalry. (...) Europeans seek the ability to interact and engage with powers, big and small, striving for a more cooperative world in our mutual interests." The EU should be more competitive and rival in achieving its global ambition.

\section{The EU-NATO relations: dependence on the US?}

Alongside the global ambitions of the EU, its relation with NATO had become more complex. European and American interests are often different. It can hardly exist a single NATO view of the world. Currently, key priorities 
for the US are China and Asia. Europe is no longer number one priority for the US, and the US expects the EU to ensure the stability of Europe's periphery. Having in mind this fact, whether they act under the NATO flag or the EU flag, European states have to take initiative by themselves to resolve the crisis around Europe. The US will no longer automatically do it on its own initiative. To what extent the EU depends on the US and NATO? This question is important because Trump's administration made it clear that those who have not contributed enough, cannot count on the support of the US. The EU should use this kind of circumstances and focus on the plan for the defence of Europe by Europeans. This kind of strategy will raise the autonomy of the EU, increase its role as a global actor, and, eventually, it will diminish dependence on the White House (Biscoup, 2018, p. 87).

The EU can reinforce its military capacities by invoking Article 42.7 of the Treaty on the European Union rather than Article 5 of The North Atlantic Treaty in cases of armed aggression on its members. Also, NATO is overshadowed by the success of the EU's maritime operations, especially against piracy in Somalia. Despite its CSDP, peacekeeping missions, the formation of PESCO, etc., the EU is not considered a military force. The US is a military force number one without any doubts. In the arena of military force, the EU can be described as a force in statu nascendi. Besides the progress of the Common Security and Defence Policy (CSDP) from soft to hard power, NATO remains the backbone of European security. In a military sense, the EU might be considered a younger brother of NATO and the US.

Cooperation between the EU and NATO had been often challenged due to the EU-Turkey relations, with Cyprus as a complicating factor. Turkey, as a NATO member, often blocks various cooperative actions between NATO and the EU. For example, in 2011, Turkey blocked the request of the EU that NATO extends protection in Afghanistan to EU police personnel if necessary (Emerson., Balfour., Corthaut, 2011, p. 104).

The EU and NATO are among the world's most important institutions. They share 21 members. Some informal comments by officials suggest a less positive story about "the two organizations living on different planets", albeit around $5 \mathrm{~km}$ away from each other (Emerson, Balfour, Corthaut, 2001, p. 104). For the future of the EU-NATO relations, some scholars suggest the replacement of NATO with a new alliance between the US and the EU or the Europeanization of NATO (Biscoup, 2018, p. 92). 


\section{The EU at the UN}

After Brexit, the EU is facing some challenges in the UN. It had lost one member in the Security Council. The United Kingdom has been an anchor of EU policy at the UN. The EU will miss British official's skills and pragmatic approach to negotiations. Brexit had arrived at a bad time for the EU at the UN, as the US, Russia, and China are challenging the liberal internationalism that the EU promotes. Brexit has the potential to deteriorate cooperation between the UK and France at the Security Council (SC). The EU expects a lot from France and Germany, who need to raise their cooperation and influence at the UN to compensate for Brexit (Gowan, 2018).

Article 34 of the Treaty of the EU provides that its members in the UN Security Council shall consult together and defend the interests of the block. To compensate for Brexit, the EU should provide these goals and unity of its members at the General Assembly (GA) as well.

The positive tendency for the EU at the UN was enhancing its observer status at the General Assembly in 2011. In accordance with GA Resolution $65 / 276$, the representatives of the European Union, in order to present the positions of the European Union and its member States as agreed by them, are:

- allowed to be inscribed on the list of speakers among representatives of major groups, in order to make interventions;

- invited to participate in the general debate of the General Assembly;

- permitted to have its communications relating to the sessions and work of the General Assembly and to the sessions and work of all international meetings and conferences convened under the auspices of the Assembly and of United Nations conferences, circulated directly, and without an intermediary, as documents of the Assembly, meeting or conference;

- permitted to present proposals and amendments orally as agreed by the States members of the European Union,

- allowed to exercise the right of reply regarding the positions of the European Union as decided by the presiding officer; such right of reply shall be restricted to one intervention per item.

Enhanced observer status of the EU in the GA is a precedent in the UN. Alongside the Lisbon Treaty and the EU Global Strategy, enhanced status in the GA "is an opportunity for the EU to achieve unity of all its members on important external policy issues" and to set the bases for its role as a global actor (Gordanić, 2017, pp. 17-18). 


\section{CONCLUSION}

The EU had shown certain duality when it comes to its regional role and global ambitions. As a regional actor, the EU had completely changed entire Europe. It brought hope after World War II, continued the growth and integration of European countries and significantly contributed progress and development of candidate countries. The EU is the world's biggest aid donor. The soft power of the EU is one of its most important mechanisms. Historically based on the principles of coordination and integration, the EU had shown its potential as a regional actor. The EU is one of the most important regional actors and an organization that is a role model for other regional arrangements. Besides its success as a regional actor, the EU is facing some challenging times. It is still looking for solutions for the main geostrategic regional challenges like relations with Turkey, the issue of Ukraine and relations with Russia, actions towards the Middle East, and the future of the enlargement policy. Brexit had shown a danger of fragmentation of the EU.

The global role of the EU had been challenged due to a diversity of interests, the crisis of European identity, the inability of strategic coordination, the complex decision-making process, and the dependence on the US. As a result of the Brexit, the role of the EU at the UN had been challenged. Besides the progress of the Common Security and Defence Policy (CSDP) from soft to hard power, NATO remains the backbone of European security. The complex nature of the EU, its structure of the supranational organization, slows down its global ambitions. For fulfilling its global ambitions, the EU should (at least theoretically) become more independent from the influence of the US. Despite all problems, the authors consider the role of the EU as a global actor challenged, not failed. Perhaps, on a global level, the EU will never become what it is on the regional level, but the EU Global Strategy from 2016 can be considered as a possible Renaissance of the EU common foreign and security policy and factor of empowerment of the EU regional role and global ambitions in international relations.

\section{LITERATURE}

Barbé, E., Morillas, P. (2019). The EU global strategy: the dynamics of a more politicized and politically integrated foreign policy, Cambridge Review of International Affairs, 32(6), 753-770. 
Beck, U., Grande, E. (2006). Kozmopolitska Europa [Cosmopolitan Europe].Zagreb, Školska knjiga.

Biscop, S. (2018). EU-NATO Relations: A Long-Term Perspective, Nação e Defesa, 150, 85-93.

Bzezinski, Z. (2009). Druga šansa Amerike: Tri predsednika i kriza američke supersile [Second Chance: Three Presidents and Crisis of American Superpower]. Beograd, Službeni glasnik.

Ćemalović, U. (2020). Towards a new strategy for EU Enlargment - between the wish for an encouragement, the reality of the fatigue and the treat of a dead end, EU and Comparative Law Issues and Challenges Series (ECLIC), 4, 281-298. https://doi.org/10.25234/eclic/11905.

Gordanić, J. (2017). Posmatrački status Evropske unije u Generalnoj skupštini Ujedinjenih nacija [Observer status of the EU in the General Assembly of the UN], Evropsko zakonodavstvo, 61-62, 9-19.

Gordanić, J. (2019). Pad multikulturalizma kao faktor jačanja nacionalnog identiteta država članica EU [The decline of multiculturalism as a factor in strengthening the national identity of the EU member states], Medunarodna politika, 1175, 5-21.

Dinan, D. (2010). Menjanje Evrope, Istorija EU [Changing of the Europe: History of the EU]. Beograd, Službeni glasnik.

Dyson, K., Sepos, A. (2010). Which Europe? The Politics of Differentiated Integration. Houndmills, Palgrave Macmillan.

Emerson, M., Balfour, R., Corthaut, T., et al. (2011). Upgrading The EU's Role as Global Actor. Brussels, Centre for European Policy Studies.

EEAS. (2016). A Global Strategy for the European Union's Foreign and Security Policy. 28 June (European External Action Service, Brussels).

EEAS. (2019). From vision to action: The EU Global Strategy in practice: Three Years on, looking forward. (European External Action Service, Brussels).

Fabrini, S. (2015). Which European Union? Europe after the Euro Crisis. Cambridge, CUP.

Grabbe, H. (2006). The EU's Transformative Power: Europeanization through Conditionality in Central and Eastern Europe. London, Palgrave Macmillan.

Has, R. (2017). Svet u neredu [World in a mess]. Beograd, CIRSD.

Judt, T. (2005). Postwar, A History of Europe since 1945. New York, Penguin Books. 
Kaplan, R. (2012). The revenge of geography. New Work, Radnom House.

Khosla, K. (2019). Is the European Union's Common Foreign and Security Policy (CFSP) adequately designed to respond to current global challenges?, International Policy Review (IPR), 01(1), 10-19.

Krastev, I., Leonard, M. (2010). The spectre of a multipolar Europe. London, ECFR.

Lopandić, D. (2018). Moguća Evropa i godine pred nama [Possible Europe in a following years]. Beograd, IES.

Lopandić, D. (2018). Postepeni razvoj Evropske unije kao bezbednosne zajednice - na putu od Venere ka Marsu [Progressive development of the EU as a security community - on the way from Venus to Mars], u: Novčić, Ž (ed), Upotreba sile u međunarodnim odnosima [Use of force in international relations] (pp. 257-273). Beograd, IMPP.

Mirel, P., Mirel, X. (2020, 25 May). Challenges and constraints facing a "Geopolitical Commission" in the achievement of European sovereignty, retrieved from https://www.robert-schuman.eu/en/ european-issues / 0560-the-challenges-and-constraints-facing-ageopolitical-commission-in-the-achievement-of-european, Accessed 15 January 2021.

Ofe, K. (2016). Evropa u zamci [Europe in a trap]. Beograd, Službeni glasnik.

Roloff, R. (2020). COVID-19 and No One's World: What Impact for the European Union?, Connections, 19 (2), 25-37.

Sampson, T. (2017). Brexit: The Economics of International Disintegration, The Journal of Economic Perspectives, 31 (4), 163-184.

Telo, M. (2016). L'Europe an crise et le monde [Europe and the world crisis]. Bruxelles, EUB.

United Nations. (3 May 2011). Resolution 65/276 adopted by the General Assembly. Participation of the European Union in the work of the United Nations, New York.

Van der Togt, T. (2020). In search of European Russia strategy, Atlantisch Perspectief, 44 (1), Special Edition: Putin's Russia, 36-41. 